\title{
The holistic specimen and parasites of mammals
}

Human population growth brings with it a huge demand for goods and services, which increases over time. It is currently recognized that the environment and biodiversity provides multiple benefits to humans beings through environmental services; however, these have been altered gradually by the use and abuse of these natural resources by society (Herrmann et al. 2016). The planet is a dynamic entity that has undergone major alterations in its physiography and lost much of its former biological diversity on multiple occasions throughout its history. Today, most of the serious environmental problems our generation faces are either caused or aggravated by human actions; some examples are the introduction of exotic species, changes of land use, or climate change. These three factors disrupt biological patterns and processes and impact ecological relationships shaped over millions of years, such as those between hosts and parasites (Brooks and Hoberg 2007).

Anthropogenic activities may foster changes in populations and communities of parasites by increasing their diversity and impairing their reproduction and infection patterns. Through the expansion or reduction of the geographic distribution of parasites, human activities also facilitate the infection of new hosts and the spread of diseases to previously disease-free places. Through micro-evolutionary processes such as sudden changes in local adaptation patterns, genetic frequencies, and natural selection of parasites associated with the emergence of diseases, humans will spark the proliferation of unregistered pathogens. The ultimate consequence would involve cascade changes in ecosystems, involving the alteration of entire communities of parasites and hosts.

In biogeography, it is known that the distribution patterns of organisms result from expansion and contraction cycles, usually triggered by historical or ecological changes (Lomolino et al. 2016). These cycles allow parasites to come into contact with new potential hosts in a given region without undergoing major adaptations. The climate change issue we currently face is expected to broaden the geographic range of parasites, leading to the emergence of new associations and diseases in regions where these were not known in the past. The expectation is that those species with greater dispersal capabilities will become sources of new diseases.

In this sense, broadening our knowledge and understanding of biodiversity and the interactions involved in it will contribute to successfully address the environmental challenges that lie ahead. To this end, museums and sci- entific collections have expanded their area of influence; currently, these promote research related to the biology and ecology of pathogens and parasites in addition to supporting classical studies of taxonomy, systematics and biogeography. Unfortunately, these institutions face serious issues derived mostly from ignorance about the utility and scientific and social potential of these unconventional areas of research, by sectors of the government, society, and academia, who claim that scientific collecting damages target populations and boosts extinctions (Malaney and Cook 2018; Minteer et al. 2014); and advocate the idea that non-invasive sampling may yield similar or better results. Consequently, there is a growing difficulty in obtaining collection permits, and there is little or no funding for the collection of new specimens or collection-based research projects; in some cases, opportunities to obtain specimens that are hard to collect through non-traditional sources (struck or hunted organisms) are wasted.

In the world and in Mexico, funds for the maintenance and growth of museums and scientific collections have decreased over the past three decades. Nonetheless, there are trends towards the management of these institutions through computerization, public and free-of-charge accesibility to databases, and creation of accessory collections. As part or extension of accessory collections, during the past decade Joe Cook, a curator of mammals at the Museum of Southwestern Biology, University of New Mexico, and his collaborators have proposed the implementation of the so-called holistic collection or holistic specimen. In the case of mammals, this is defined as the collection of specimens along with their endo- and ectoparasites, microbiome, and even samples of the associated soil and plants. The potential benefits are multiple, since this approach addresses not only the study of the target species sampled, but also their context (Schindel and Cook 2018). The holistic collection or holistic specimen approach allows maximizing efforts and financial resources used in a collecting expedition; also, the specimens and information collected can be used in studies ranging from molecular biology (phylogeography, population genetics, molecular systematics, gene expression), to ecosystems (ecology of populations and communities, among others), which strengthen interdisciplinary work (Brooks and Hoberg 2007). Collecting specimens under the holistic approach allows making inferences about ecological interactions, potential impact on human and animal health, environmental quality, and even food and national security. Collections of parasites 
of mammals can unveil the dynamics of potential vectors, and identify reservoirs of pathogens and potential sources of agricultural pests and their likely controlling drivers. In addition, these facilitate the comparison of samples collected under different temporary and geographic contexts, to delineate the past, current, and, above all, the potential distribution of parasites, as well as their ecology and transmission pathways (Schindel and Cook 2018).

In particular, with regard to mammals, there are excellent publications that review their evolution, taxonomy, systematics, biogeography, ecology, or behavior. However, a component of mammal biology that has often been overlooked is the association with a megadiverse group of organisms commonly known as parasites that groups together several taxa of invertebrates. The knowledge of parasites of mammals is, at best, incomplete, although there are partial listings of helminths (Galbreath et al. 2019; Garcia-Prieto et al. 2012; Falcon-Ordaz et al. 2015), fleas (Salceda and Hastriter 2006), mites and ticks (Guzman et al. 2016). It is reasonable to state that these are partial listings, as the authors themselves acknowledge the lack of studies in their respective groups and underline the scarcity of publications or museum records for multiple Mexican states. From my own perspective, this issue can be addressed by implementing holistic sampling and consolidating or building academic associations between mammalogists and parasitologists, which has proven to be both long-standing and fruitful. The joint work of these two groups of professionals have yielded pivotal contributions to document the biodiversity of mammals and parasites, and some have also set the grounds for public policies regarding the management and containment of diseases with zoonotic potential such as rabies (Villa, 1966).

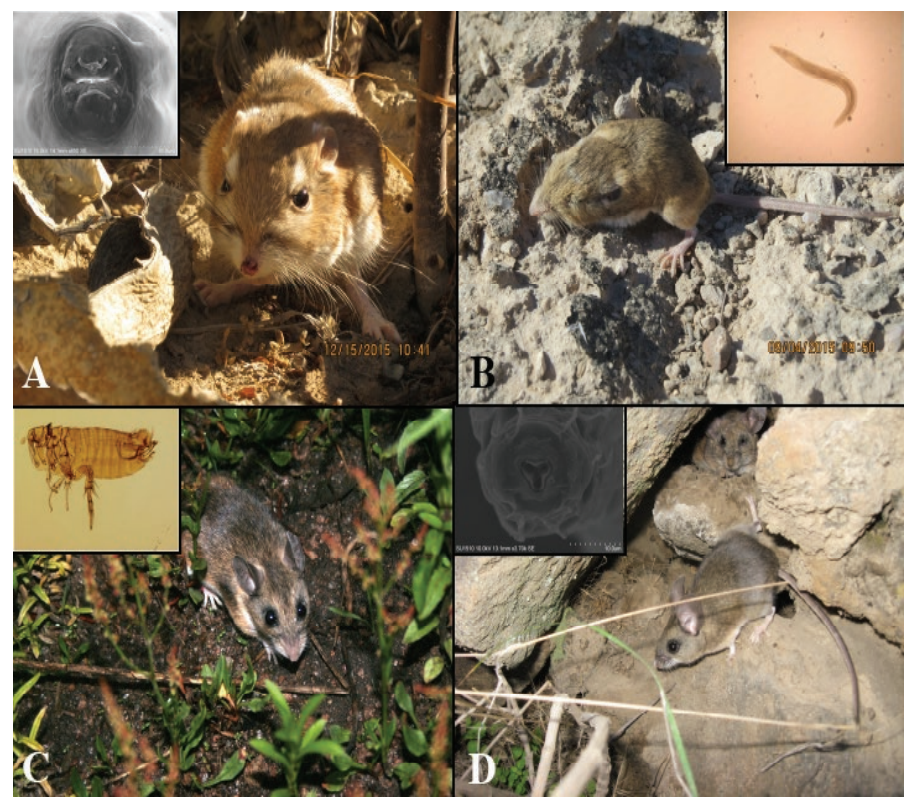

Figure 1. Endo- and ectoparasites of wild mammals. A. Protospirura dipodomis collected from Dipodomys merriami (Photographs: Jorge Falcón Ordáz [P. dipodomis], Jesús A. Fernández [D. merriami, Mexico, Coahuila]); B. Heteromyoxyuris otomii collected from Perognathus flavus (Photographs: Jorge Falcón Ordáz [H. otomii], Jesús A. Fernández [P. flavus, Mexico, Chihuahua]); C. Plusaetis sibynus collected from Peromyscus melanotis (Photographs: Roxana Acosta Gutiérrez [P. sibynus], Juan Cruzado [P. melanotis, Mexico, Chihuahua]); D. Shyphacia peromysci collected from Peromyscus difficilis (Photographs: Jorge Falcón Ordáz [S. peromysci]), Jesús A. Fernández [P. difficilis, Mexico, Veracruz]).
Then, mammalogists and parasitologists are encouraged here to organize joint expeditions covering the collection of both mammals and parasites, in order to mitigate the gaps in the knowledge of both groups. Contributions to this knowledge will allow to successfully confront the fact that, as a result of the change in global temperature, both mammals and their pathogens and parasites will expand or contract their distribution areas, possibly parasitizing new hosts, leading to the emergence of new health issues for humans, domestic animals, and wildlife, and also regarding the interactions between them.

This special issue contains studies addressing the correspondence between the phylogeny of hosts and parasites (Popinga et al. 2019); identification of communities of mammals and ectoparasites in Argentina (Lareschi et al. 2019); documentation of new records and geographic extensions of parasites and pathogens of importance for human health (Alvarez-Córdova et al. 2019; Gutierréz-Molina et al. 2019; Panti-May et al. 2019; Pulido-Flores et al. 2019; SánchezMontes et al. 2019); annotated lists of parasite taxa (Light et al. 2019); and use of museum records to derive potential distribution areas (Botero-Canola et al. 2019).

I am grateful for the invitation received by AMMAC through its editor-in-chief to edit this special issue; also, to all authors and reviewers who kindly agreed to contribute to this project; and to J. Falcón and F. Garcia C. for reviewing early versions of this contribution.

\section{Literature cited}

Álvarez-Córdova, F., J. A. Fernández, E. A. Martínez-Salazar, and R. Rosas-VALDEZ. 2019. First record of the genus Physaloptera sp. (Nemata: Physalopteridae) in scats from coyote, Canis latrans in Chihuahua, México. Therya 10: 183-185.

Botero-Canola, S., A. T. Dursahinhan, S. E. Racz, P. V. Lowe, J. E. UbelakeR, and S. L. Gardner. 2019. The ecological niche of Echinococcus multilocularis in North America: understanding biotic and abiotic determinants of parasite distribution with new records in New Mexico and Maryland, United States. Therya 10:91-102.

BRooks, D. R., AND E. P. Hoberg. 2007. How will global climate change affect parasite-host assemblages? Trends in Parasitology 23:571-574.

Falcón-Ordaz, J., S. Monks, G. Pulido-Flores, L. García-Prieto, and G. LiRA-Guerrero. 2015. Riqueza de Helmintos parásitos de vertebrados silvestres del estado de Hidalgo, México. Pp. 20 37 in Estudios de Biodiversidad (Pulido-Flores, G., S. Monks, and M. López-Herrera, ed.). Zea Book, University of Nebraska. Lincoln, U. S. A.

Galbreath, K., E. Hoberg, J. Cook, B. Armien, K. Bell, M. Campbell, J. Dunnum, A. Dursahinhan, R. Eckerlin, S. Gardner, S. Greiman, H. Henttonen, F. Jiménez, A. Koemler, B. Nyamsuren, V. Tkach, F. Torres-Pérez, A. Tsvetkova, AND A. HoPE. 2019. Building an integrated infrastructure for exploring biodiversity: field collections and archives of mammals and parasites. Journal of Mammalogy 100:382-393.

Garcia-Prieto, L., J. Falcón-Ordaz, and C. Guzmán-Cornejo. 2012. Helminth parasites of wild Mexican mammals: list of species, hosts and geographical distribution. Zootaxa 3290:1-92. 
Gutierréz-Molina, R., A. Cruz-Romero, D. Romero-Salas, G. BalladosGonzález, J. Jiménez-Hernández, N. Ibarra-Priego, R. Serna-Lagunes, AND S. SÁNCHEZ-Montes. 2019. Molecular evidence for the presence of Leptospira borgpetersenii in synanthropic rodents in the Nautla region, Veracruz, Mexico. Therya 10:171-174.

Guzmán-Cornejo, C., R. G. Robbins, A. A. Guglielmone, G. MontielParra, G. Rivas, And T. M. Pérez. 2016. The Dermacentor (Acari, Ixodida, Ixodidae) of Mexico: hosts, geographical distribution and new records. Zookeys 569:1-22.

Herrmann, D. L., K. Schwarz, W. D. Shuster, A. Berland, B. C. Chaffin, A. S. Garmestani, and M. E. Hopton. 2016. Ecology for the shrinking city. Bioscience 66:965-973.

Lareschi, M., E. Savchenko, and M. Urdapilleta. 2019. Ectoparasites associated with sigmodontine rodents from northeastern Argentina. Therya 10:103-108.

Light, J. E., R. P. Eckerlin, And L. A. Durden. 2019. Checklist of ectoparasites of Canidae and Felidae in México. Therya 10:

Lomolino, M.V., B. R. RiddLE, AND R. J.WHITTAKER. 2016. Biogeography. Sinahuer Associates.

MalaneY, J. L., AND J. A. CoOK. 2018. A perfect storm for mammalogy: declining sample availability in a period of rapid environmental degradation. Journal of Mammalogy 99:773-788.

Minteer, B. A., J. P. Collins, K. E. Love, and R. Puschendorf. 2014. Ecology. Avoiding (re)extinction. Science 344:260-261.

Panti-May, J., S. F. Hernández-Betancourt, and L. García-Prieto. 2019. Hydatigera taeniaeformis (Cestoda: Taeniidae) in the Yucatán squirrel Sciurus yucatanensis (Rodentia: Sciuridae), México. Therya 10: 179-182.

Popinga, A. J. W. Demastes, T. A. Spradling, D. J. Hafner, and M. S. HAFNER. 2019. Host-parasite associations of the Cratogeomys fumosus species group and their chewing lice, Geomydoecus. Therya 10:81-89.

Pulido-Flores, G., S. Monks, And J. Falcón-Ordaz. 2019. Distribution extension of Aspiculuris americana parasite of Peromyscus difficilis in Hidalgo, Mexico. Therya 10:175-178.

Salceda-Sánchez, B., AND M. W. Hastriter. 2006. A list of the fleas (Siphonaptera) of Mexico with new host and distribution records. Zootaxa 1296: 29-43.

Sánchez-Montes, S., M. Y. Cabrera-Garrido, C. A. Ríos-Muñoz, A. Z. Lira-Olguin, R. Acosta-Gutiérrez, M. Mata-Galindo, K. HernándezVilchis, D. M. Navarrete-Sotelo, P. Colunga-Salas, L. León-Paniagua, AND I. BECKER. 2019. Detection of Bartonella and Rickettsia in small mammals and their ectoparasites in México. Therya 10: SCHINDEL, D. E., AND J. A. Cook. 2018. The next generation of natural history collections. PLoS Biol 16(7):e2006125. https:// doi.org/10.1371/journal. pbio.2006125

VILLA, R. B. 1966. Los murciélagos de México. Instituto Nacional de Biología, U.N.A.M., México.

Jesús A. FernÁNDEZ ${ }^{1 *}$

${ }^{1}$ Departamento de Recursos Naturales, Facultad de Zootecnia y Ecología, Universidad Autónoma de Chihuahua. Periférico Francisco R. Almada Kilómetro 1, Zootecnia, CP 31415, Chihuahua. Chihuahua, México. Email afernandezf@uach.mx

*Correspondencia 
68 THERYA Vol. 10 (2): 65-67 